\title{
Natural Killer T cells in Egyptian Patients with HCV-associated Non-alcoholic Fatty Liver Disease
}

\author{
Raghda K. Ali, ${ }^{1,6}$, Soha E. Younes ${ }^{1,4}$, Adel A. Hassan ${ }^{2,4}$, Amany M. Hassan ${ }^{1,4}$, \\ Amro A. El-Sakka ${ }^{3,4}$, Rasha Emad ${ }^{1,5}$, and Howayda M. Hassoba ${ }^{1,3^{*}}$ \\ ${ }^{1}$ Department of Clinical Pathology, ${ }^{2}$ Department Tropical Medicine, ${ }^{3}$ Fifth year Medical Student, ${ }^{4}$ Faculty of \\ Medicine, Suez Canal University, ${ }^{5}$ Faculty of Medicine, Port Said University, ${ }^{6}$ Ismailia Oncology Hospital, Egypt
}

\begin{abstract}
Background: Studies on Natural Killer T (NKT) cells in Non-alcoholic fatty liver disease (NAFLD) have shown contradictory results. Moreover, the effect of HCV superinfection on NKT cells in NAFLD patients have not been previously studied. Aim: to assess the effect of the concomitant $\mathrm{HCV}$ infection on the frequency of NKT cells and CD8+ T cells in a cohort of Egyptian patients with hepatic steatosis. Subjects and Methods: Two-hundred subjects were divided into four equal groups, 1) concomitant hepatic steatosis/HCV, 2) HCV (without steatosis), 3) steatosis (without HCV), and 4) normal controls. NKT and CD8+ T cells were identified by monoclonal antibodies surface staining for $\left(C_{3}, C D_{5} 6, C D_{161}\right)$, and (CD3, CD8) respectively using flow cytometry. Results: $\mathrm{CD}_{3}{ }^{+} / \mathrm{CD}_{56} 6^{+} / \mathrm{CD}_{161^{+}} \mathrm{NKT}$ cells were significantly higher in patients with either steatosis (alone) or concomitant $\mathrm{HCV} /$ steatosis compared to control ( $p<0.0001$ each), while comparable NKT frequency was found between HCV group and control $(p=0.72)$. A significant increase in $\mathrm{CD}_{3} / \mathrm{CD}^{+} \mathrm{T}$ cells was noted in the three patients' groups compared to control $(p=0.0001,0.002$ and 0.001 , respectively). Interestingly, NKT cells were significantly higher in patients with steatosis/HCV compared to those with HCV alone $(p<0.0001)$, while, they did not differ between concomitant HCV/steatosis and steatosis (alone) group. Higher frequencies of both NKT cells and $\mathrm{CD}^{+} \mathrm{T}$ cells were significantly associated with increased severity of steatosis. In HCV group, NKT frequencies were unrelated to steatosis severity. Conclusion: NKT cells are significantly elevated in patients with hepatic steatosis irrespective to the presence or absence of concomitant HCV infection.
\end{abstract}

Key Words: NKT, CD8+ T, steatosis, Egypt, HCV

\section{Introduction}

Non-alcoholic fatty liver disease (NAFLD) is a worldwide health problem with a prevalence as high as $17 \%-33 \%$ in western countries $^{(1)}$. NAFLD has been used as a general name for conditions ranging from simple benign steatosis through non-alcoholic steatohepatitis (NASH) to cirrhosis or even hepatocellular carcinoma ${ }^{(2,3)}$. Hepatosteatosis is defined as fat deposition in the liver that exceeds $5 \%$ of the total weight of the liver, or the presence of microscopic fat deposits in more than $5 \%$ of the hepatocytes $^{(4)}$. Hepatic steatosis was reported frequently in HCV infection with multifactorial etiology. It may be the result of a direct virologic effect particularly in patients

*Corresponding Author: hhassoba@yahoo.com 
infected with HCV genotype 3. Also, it may be associated with known steatosis risk factors such as obesity, diabetes mellitus and hypertriglyceridemia ${ }^{(4,5)}$. The presence of steatosis in liver biopsy specimens from patients with chronic HCV infection has been reported in $\sim 50 \%$ of the cases $^{(6)}$. Moreover, a role for steatosis in the progression of chronic HCV infection had been reported ${ }^{(7)}$. Hepatic steatosis was an independent risk factor for hepatocarcinoma in patients with chronic HCV infection ${ }^{(8)}$. However, the pathogenesis of steatosis in patients with HCV is not well understood. Natural killer T (NKT) cells are a highly conserved subset of lymphocytes that share properties of both $\mathrm{T}$ cells $\left(\mathrm{CD}_{3}{ }^{+}\right.$expression) and natural killer (NK) cells (CD56 $6^{+}$ and $\mathrm{CD}_{161^{+}}$expression) $)^{(9)}$. Many functions for this unique cell have been proposed, ranging from antitumor activity to autoimmune diseases ${ }^{(10)}$ however, the exact role of NKT cells in immunity has yet to be fully elucidated. NKT cells have been reported in association with various lipid disorders; they may enhance disease activity through cytokine production after the recognition of lipid antigens presented with CD1d in the livers of NAFLD ${ }^{(11)}$. NKT cells comprise $30 \%$ $50 \%$ of all hepatic lymphocytes. These cells can be directly cytotoxic via FasL-dependent and perforin-mediated mechanisms but can also produce an array of cytokines that direct cytokine secretion by other cells within their microenvironment. These functions may be responsible for cell death seen in NAFLD ${ }^{(12)}$. Murine models of obesity and fatty liver disease have linked NAFLD with the depletion of NKT cells ${ }^{(13)}$. Later human studies have reported a depletion of peripheral blood NKT cells in patients with clinically diagnosed NALFD ${ }^{(14)}$, while, intrahepatic NKT cells were either depleted $^{(15)}$, or increased ${ }^{(11,16)}$. The loss of CD4-expressing NKT cells is particularly intriguing as this cell subset is believed to pri- marily secrete Th2-type cytokines, including IL-4 and IL-13. This loss of Th2 cytokines might tip the inflammatory milieu of the liver into a pro-inflammatory Th1 state, leading to excessive production of TNF- $\alpha$ and IFN- $\gamma$. The increase in pro-inflammatory cytokines likely plays a role in hepatic oxidative stress and recruitment of additional inflammatory cells into the liver, resulting in $\mathrm{NASH}^{(17)}$. $\mathrm{CD} 8+\mathrm{T}$ cells are important in viral eradication by direct killing of infected cells and secretion of antiviral cytokines [IFN- $\gamma$ or tumor necrosis factor (TNF)- $\alpha]^{(18)}$. Despite the detection of HCVspecific CD8+ T cells in the peripheral blood and the intrahepatic lymphocytic infiltrate in patients with chronic hepatitis C, the virus can persist. This persistence is unexplained and suggests that cell killing is not adequate to eliminate the virus. Studies in humans have revealed that even strong $C D 8+T$ cell responses in the acute infection may not be adequate to prevent progression to chronicity ${ }^{(19-21)}$. Some studies have suggested functional defects in HCV-specific CD8+ $T$ cells during chronic infection, as indicated by impaired IFN- $\gamma$ production, cytotoxic effector functions, and in vitro proliferation $^{(22,23)}$. Earlier studies have demonstrated that lipotoxic hepatocyte injury plays the key role in recruiting intrahepatic and extrahepatic antigen presentation cells, neutrophils, and lymphocytes to the steatotic liver. The subset of immune cells that are primarily responsible for NASH progression is still largely unknown. Recently, the role and abundance of CD8+T-cells were highlighted when depletion of CD8+T-cells was shown to result in decreased fibrosis in a high-fructose diet murine NASH model(24). The role of both NKT and CD8 + T cells in hepatic steatosis in association with $\mathrm{HCV}$ infection and how would the concomitant presence of $\mathrm{HCV}$ affect NAFLD the has not yet been clarified. Understanding the potential role of 
these cells would presents novel therapeutic strategies for the treatment of both NAFLD and NASH. Thus, the current study aimed to assess the characterization of the peripheral $\mathrm{CD}_{3}{ }^{+} \mathrm{CD} 56^{+} \mathrm{CD} 161^{+} \mathrm{NKT}$ and $\mathrm{CD} 8^{+}$ cells in a cohort of Egyptian patients with $\mathrm{HCV}$-associated hepatic steatosis and to analyze the relationship of these cell to the disease severity.

\section{Subjects and Methods}

This cross-sectional study was conducted on 200 subjects divided into 4 groups (50 subject each). Group 1: patients with HCVassociated hepatic steatosis, Group 2: patients with HCV (without hepatic steatosis), Group 3: patients with hepatic steatosis (without HCV infection), and Group 4: Apparently healthy blood donors as a normal control group (anti-HCV negative, and steatosis-free by abdominal US). Patients $\geq$ 18 years old were included in the study if they have i) histologically-proven liver steatosis based on liver biopsy (for groups 1, and 2). ii) persistent elevation in liver transaminases (ALT and AST) for $\geq 6$ months. iii) positive serologic and virologic lab tests for HCV infection (i.e. positive anti-HCV by ELISA and positive HCV RNA by RT-PCR) (for groups 1 and 2). Patients with concomitant positive serology for HBV and/or HIV infections, alcoholic fatty liver disease (AFLD), excessive alcohol intake (>30 g/ day), prior HCV antiviral therapy, history of autoimmune diseases, or current immunosuppressive therapy were excluded from the study. The Study was approved by the IRB of the Suez Canal University and all the patients were consented prior to inclusion in the study. All the study populations were subjected to a structured interview using a pre-designed questionnaire that included history of HBV and or HIV infections, drug history of antiviral, immunomodulatory or hepatotoxic drugs, history of any chronic illness or autoimmune diseases. Patients were evaluated clinically by a GIT specialist.

\section{Laboratory Investigations:}

Routine blood tests: Morning blood samples $(5 \mathrm{ml})$ were obtained from patients and controls after at least 12 hours fasting to perform the following: 1) liver function tests ALT, AST, and Alkaline phosphatase and serum lipid profile (Cholesterol, TG, LDL, HDL) using automated chemistry analyzer (COBAS e411 Roche diagnostics, Germany). 2) Complete blood count (CBC): using automated cell counter (Sysmex XT 5 parts differential cell counter, Germany). The results of HCV antibody serology and HCV-RNA were obtained from patients' records.

Assessment of NKT cells phenotyping by flow cytometry: NKT cells were identified by monoclonal antibodies surface staining for (CD3, CD56, CD161), followed by flow cytometric analysis using FACS calibur flow cytometry (Becton Dickinson Immunocytometry Systems, USA). Data were analyzed using the Cell Quest software. Procedure: Two $\mathrm{mL}$ venous blood were obtained in an EDTA-tube. Three FACS tubes were prepared for each sample as follows: Tube $\# 1=$ unstained, Tube $\# 2=$ for $C_{3}$ (percp) and CD8 (PE), Tube \#3: for CD3 (percp), CD56 (PE), and CD161(FITC). A hundred $\mu \mathrm{l}$ of blood samples were added to the FACS tubes. CD3 $(5 \mu \mathrm{l})$, and $\mathrm{CD} 8(5 \mu \mathrm{l})$ were added to the blood in tube \#2. While, $\mathrm{CD}_{3}$ $(5 \mu \mathrm{l}), \mathrm{CD}_{56}(5 \mu \mathrm{l})$ and CD161 $(5 \mu \mathrm{l})$ were added to the blood in tube \#3. The tubes were vortexed and incubated for $20 \mathrm{~min}$ at $4^{\circ} \mathrm{C}$. Lysing solution $(2 \mathrm{ml})$ was added to each tube and vortexed. The tubes were incubated at room temperature in a dark place for $10 \mathrm{~min}$. Tubes were spinned at $1500 \mathrm{rpm}$ for $5 \mathrm{~min}$ and the supernatants were discarded. The washing step was done by adding $2 \mathrm{ml}$ of PBS and centrifugation at 1500 rpm for 5 min. Data Analysis: 
Lymphocytes were gated according to their light scatters' properties on the lower part of both forward and side scatters. $T$ cells were identified as the $\mathrm{CD}_{3}+$ cells by using dot plot quadrants. NKT cells were identified as $\mathrm{CD}_{3}^{+} / \mathrm{CD}_{5} 6^{+}$cells and $\mathrm{CD}_{3}{ }^{+} /$ CD $56^{+} / \mathrm{CD} 161^{+}$cells Percentages of the cells were identified by using Cell Quest software statistics.

Radiological assessment: Hepatic ultrasonography was used to: 1- diagnose hepatic steatosis in group 3 (steatosis group) and 2- exclude steatosis in group 4 (normal control).

Histopathological assessment: Liver biopsies were performed by a pathologist for patients in group 1 (steatosis/ HCV) and group 2 (HCV) to assess the degree of hepatic steatosis using the following staging system: Mild (steatosis involving up to $33 \%$ of hepatocytes), Moderate (steatosis involving $33 \%-66 \%$ of hepatocytes) and Severe (steatosis involving more than $66 \%$ of hepatocyte) ${ }^{(25)}$.

\section{Statistical Analysis}

Statistical analyses were done using the software Statistical Package for the Social Sciences (SPSS) version 20. Conventional student $t$-test and analysis of variance (ANOVA) were used to detect significant difference between continuous variables in two or more groups, respectively. Chisquare test was used for categoric variables. Spearman's correlation coefficient ( $r$ ) was used to estimate different correlations between variables. $P$ values of less than 0.05 or a $95 \%$ confidence interval $(\mathrm{Cl})$ that did not span 1.00 was considered statistically significant.

\section{Results}

Study population characteristics: The demographic, laboratory and histological characteristics of the four studied populations are demonstrated in Table $1 . \mathrm{HCV}$ viral load was significantly higher in patients with concomitant steatosis and HCV compared to patients with HCV alone (1.0 0.11 vs. $0.4 \pm 0.04$ copies $\left./ \mathrm{ml} \mathrm{x10}^{6}, p=0.03\right)$. Patients with steatosis had the highest mean BMI $\left(36.8 \pm 3.9 \mathrm{~kg} / \mathrm{m}^{2}\right)$, followed by patients with concomitant steatosis and HCV $\left(33.9 \pm 4.0 \mathrm{~kg} / \mathrm{m}^{2}\right)$, and lastly patients with HCV $\left(29.3 \pm 2.9 \mathrm{~kg} / \mathrm{m}^{2}\right)(p=0.001)$. The degree of hepatic steatosis was assessed histologically in patients with mixed HCV and steatosis. More than half of the patients (56\%) had mild steatosis, while moderate and severe steatosis were found in $24 \%$ and in $20 \%$ respectively. In patients with steatosis (without HCV infection), the fatty changes were assessed by ultrasound imaging and revealed moderate steatosis in the all the patients

Frequency of peripheral NKT and $C D 8^{+} T$ cells in patients versus control: We compared the frequency of NKT cells and CD8 ${ }^{+} T$ cells in each patient group compared to normal control group. $\mathrm{CD}_{3}^{+} / \mathrm{CD}_{5} 6^{+} / \mathrm{CD}_{161^{+}} \mathrm{NKT}$ cells were significantly higher in patients with either steatosis or concomitant $\mathrm{HCV} /$ steatosis compared to control (7.1 \pm 4.5 and $8.8 \pm 5.8$ vs. $4.2 \pm 1.6, p<0.0001$ each), While comparable NKT frequency was found between HCV group and normal control $(p=0.72)$. Interestingly, percentage of $\mathrm{CD}_{3}{ }^{+} / \mathrm{CD}_{5} 6^{+} \mathrm{NKT}$ did not differ between patients and control group. As regards $\mathrm{CD}^{+} / \mathrm{CD}^{+} \mathrm{T}$ cells, a significant increase was noted in the three patients; groups compared to control (Table 2).

NKT cells in patients with steatosis in relation to HCV infection: Using the most common phenotypic definitions of NKT cells, we compared the percentage of $\mathrm{CD}_{3}+/ \mathrm{CD}_{56} 6+\mathrm{NKT}$ and $\mathrm{CD}_{3}+/ \mathrm{CD}_{56} 6+/ \mathrm{CD}_{161+}$ NKT cells in the peripheral blood of the three patients' populations. To study the 
effect of HCV infection on the frequency of NKT cells, we compared patients with concomitant HCV and steatosis to those with steatosis alone and found no significant difference in the percentages of NKT cells $\left(\mathrm{CD}_{3}{ }^{+} / \mathrm{CD}_{5} 6^{+}\right)$or NKT cells $\left(\mathrm{CD}^{+} /\right.$ $\left.\mathrm{CD} 56^{+} / \mathrm{CD} 161^{+}\right)$between both groups $(\mathrm{p}=$ 0.97 and 0.10 respectively) (Table 3 ).

Table 1: Characteristics of the study populations

\begin{tabular}{|c|c|c|c|c|}
\hline \multirow[b]{2}{*}{ Variables } & \multicolumn{3}{|c|}{ Patients' groups } & \multirow[b]{2}{*}{$\begin{array}{l}\text { Control } \\
(n=50)\end{array}$} \\
\hline & $\begin{array}{c}\text { Steatosis/HCV } \\
\quad(n=50)\end{array}$ & $\begin{array}{c}\mathrm{HCV} \\
(\mathrm{n}=50)\end{array}$ & $\begin{array}{l}\text { Steatosis } \\
(n=50)\end{array}$ & \\
\hline Age (years) & $47.2 \pm 7.7$ & $38.6 \pm 9.8$ & $44.8 \pm 8.8$ & $29 \pm 3.8$ \\
\hline Male No. (\%) & $13(65 \%)$ & $19(5 \%)$ & $15(75 \%)$ & $12(60 \%)$ \\
\hline $\mathrm{BMI}\left(\mathrm{kg} / \mathrm{m}^{2}\right)$ & $33.9 \pm 4.0$ & $29.3 \pm 2.9$ & $36.8 \pm 3.9$ & $24.9 \pm 2.3$ \\
\hline $\mathrm{HB}(\mathrm{mg} / \mathrm{dL})$ & $13.6 \pm 1.7$ & $14.7 \pm 1.3$ & $12.2 \pm 1.6$ & $13 \pm 1.4$ \\
\hline $\operatorname{PLT}\left(\mathrm{x} 10^{3} / \mu \mathrm{L}\right)$ & $204 \pm 65$ & $187 \pm 61$ & $253 \pm 70$ & $244 \pm 75$ \\
\hline $\operatorname{TLC}\left(\times 10^{3} / 10^{3} / \mu \mathrm{L}\right)$ & $6.4 \pm 2.0$ & $6.3 \pm 1.8$ & $7.1 \pm 1.9$ & $6.6 \pm 2.1$ \\
\hline $\operatorname{ALT}(\mathrm{U} / \mathrm{L})$ & $58 \pm 16$ & $55 \pm 18$ & $28 \pm 9$ & $20 \pm 9$ \\
\hline $\operatorname{AST}(U / L)$ & $61 \pm 25$ & $51 \pm 16$ & $29 \pm 12$ & $25 \pm 9$ \\
\hline Bilirubin (mg/dL) & $2.2 \pm 0.9$ & $1.7 \pm 0.5$ & $0.92 \pm 0.2$ & $0.78 \pm 0.2$ \\
\hline Albumin (g/dL) & $3.4 \pm 0.4$ & $3.4 \pm 0.4$ & $3.7 \pm 0.4$ & $4.1 \pm 0.4$ \\
\hline $\mathrm{CHOL}(\mathrm{mg} / \mathrm{dL})$ & $136 \pm 18$ & $109 \pm 19$ & $135 \pm 15$ & $98 \pm 9$ \\
\hline $\mathrm{TG}(\mathrm{mg} / \mathrm{dL})$ & $102 \pm 22$ & $79 \pm 21$ & $111 \pm 16$ & $79 \pm 11$ \\
\hline LDL (mg/dL) & $75 \pm 16$ & $51 \pm 20$ & $68 \pm 20$ & $39 \pm 8$ \\
\hline $\mathrm{HDL}(\mathrm{mg} / \mathrm{dL})$ & $41 \pm 4$ & $42 \pm 6$ & $45 \pm 7$ & $41 \pm 4$ \\
\hline HCV-RNA (copies/mL) x10 & $1.0 \pm 0.11$ & $0.4 \pm 0.04$ & - & - \\
\hline \multicolumn{5}{|l|}{ Steatosis } \\
\hline No & 0 & $50(100 \%)$ & 0 & $50(100 \%)$ \\
\hline Mild & $28(56 \%)$ & 0 & 0 & 0 \\
\hline Moderate & $12(24 \%)$ & 0 & $50(100 \%)$ & 0 \\
\hline Severe & $10(20 \%)$ & 0 & 0 & 0 \\
\hline
\end{tabular}

$\mathrm{BMI}=$ Body mass index, $\mathrm{HB}=$ Hemoglobin, $\mathrm{PLT}=$ Platelet, $\mathrm{TLC}=$ Total leucocytic count, $\mathrm{ALT}=$ Alanine aminotransferase, AST=Aspartate aminotransferase, $\mathrm{CHOL}=$ Cholesterol, TG=Triglyceride, LDL=Low-density lipoprotein, HDL=High-density lipoprotein, HCV RNA= Hepatitis C virus RNA. All data are presented as mean \pm SD EXCEPT gender

Table 2: Distribution of lymphocytes subsets in the studied population

\begin{tabular}{|l|c|c|c|c|c|c|c|c|}
\hline Type of cells (\%) & $\begin{array}{c}\text { Steato/HCV } \\
(\mathrm{n}=50)\end{array}$ & $\begin{array}{c}\mathrm{HCV} \\
(\mathrm{n}=50)\end{array}$ & $\begin{array}{c}\text { Steatosis } \\
(\mathrm{n}=50)\end{array}$ & $\begin{array}{c}\text { Control } \\
(\mathrm{n}=50)\end{array}$ & $\mathrm{P}$ & $\mathrm{P}^{1}$ & $P^{2}$ & $P^{3}$ \\
\hline Lymphocytes (Total) & $41.5 \pm 8.8$ & $43.1 \pm 9.6$ & $35.7 \pm 9.4$ & $39.9 \pm 13.2$ & 0.4 & 0.47 & 0.06 & 0.16 \\
\hline $\mathrm{CD}^{+}$ & $63.2 \pm 9.6$ & $63.8 \pm 8.5$ & $67.9 \pm 6.9$ & $69.1 \pm 4.7$ & $\mathbf{0 . 0 4}$ & $\mathbf{0 . 0 0 0 2}$ & 0.31 & $\mathbf{0 . 0 0 0 2}$ \\
\hline $\mathrm{CD}^{+} / \mathrm{CD}^{+}$ & $41.9 \pm 8.6$ & $40.4 \pm 8.8$ & $42.1 \pm 12.3$ & $35.9 \pm 5.4$ & 0.12 & $\mathbf{0 . 0 0 0 1}$ & $\mathbf{0 . 0 0 1}$ & $\mathbf{0 . 0 0 2}$ \\
\hline $\mathrm{CD}^{+} / \mathrm{CD}_{5} 6^{+}$ & $20.9 \pm 16.9$ & $18.6 \pm 17.7$ & $21 \pm 15.9$ & $20.5 \pm 12.5$ & 0.9 & 0.89 & 0.86 & 0.53 \\
\hline $\mathrm{CD}^{+} / \mathrm{CD}_{5} 6^{+} / \mathrm{CD}_{161}{ }^{+}$ & $8.8 \pm 5.8$ & $4.4 \pm 3.7$ & $7.1 \pm 4.5$ & $4.2 \pm 1.6$ & $\mathbf{0 . 0 0 1}$ & $<\mathbf{0 . 0 0 0 1}$ & $<0.0001$ & 0.72 \\
\hline
\end{tabular}

$\mathrm{P}$ all patients 'groups vs. control (ANOVA test), Significant $\mathrm{p}$-value at $<0.05$, highly significant $\mathrm{p}$-value at $<0.01$ $\mathrm{P}^{1}=$ Steatosis/HCV vs. control (T-test), $\mathrm{P}^{2}=$ Steatosis vs. control (T-test), $\mathrm{P}^{3}=\mathrm{HCV}$ vs. control (T-test)

On the other hand, and to assess the effect of steatosis on the frequency of NKT cells, we compared patients with concomitant $\mathrm{HCV}$ and steatosis to those with HCV alone. The percentages of NKT cells $\left(\mathrm{CD}_{3}+\mathrm{CD}_{5} 6^{+} / \mathrm{CD}_{16} 1^{+}\right)$were significantly higher in patients with steatosis/HCV compared to those with HCV alone $(p<0.0001)$. While no difference in the percentages of NKT cells of the phenotype $\mathrm{CD}_{3}{ }^{+} / \mathrm{CD}_{5} 6^{+}$ was found between both groups $(p=0.50)$. No difference was found in the frequency 
of $\mathrm{CD}^{+} \mathrm{T}$ between steatosis/HCV group and either steatosis or HCV groups $(p=0.92$ and 0.39 respectively) (Table 3 ) (Figure 1a, 1b)

Table 3: NKT cells in concomitant HCV/steatosis versus eitherHCV or steatosis alone

\begin{tabular}{|l|c|c|c|c|c|}
\hline Type of cells (\%) & $\begin{array}{c}\text { Steatosis/HCV } \\
(n=50)\end{array}$ & $\begin{array}{c}\text { Steatosis } \\
(n=50)\end{array}$ & $\begin{array}{c}\mathrm{HCV} \\
(\mathrm{n}=50)\end{array}$ & $\mathrm{P}^{1}$ & $\mathrm{P}^{2}$ \\
\hline Lymphocytes (Total) & $41.5 \pm 8.8$ & $35.7 \pm 9.4$ & $43.1 \pm 9.6$ & $\mathbf{0 . 0 0 1}$ & 0.38 \\
\hline $\mathrm{CD}^{+}$ & $63.2 \pm 9.6$ & $67.9 \pm 6.9$ & $63.8 \pm 8.5$ & $\mathbf{0 . 0 0 6}$ & 0.74 \\
\hline $\mathrm{CD}^{+} / \mathrm{CD}^{+}$ & $41.9 \pm 8.6$ & $42.1 \pm 12.3$ & $40.4 \pm 8.8$ & 0.92 & 0.39 \\
\hline $\mathrm{CD}^{+} / \mathrm{CD}^{+} 6^{+}$ & $20.9 \pm 16.9$ & $21 \pm 15.9$ & $18.6 \pm 17.7$ & 0.97 & 0.50 \\
\hline $\mathrm{CD}^{+} / \mathrm{CD}_{5} 6^{+} / \mathrm{CD}_{161}{ }^{+}$ & $8.8 \pm 5.8$ & $7.1 \pm 4.5$ & $4.4 \pm 3.7$ & 0.10 & $<\mathbf{0 . 0 0 0 1}$ \\
\hline
\end{tabular}

Independent samples T-test (significant p-value at $<0.05$; highly significant p-value at $<0.01$ ), Significant $p$-value at <0.05; highly significant $\mathrm{p}$-value at $<0.01, \mathrm{P}^{1}=$ Steatosis $/ \mathrm{HCV}$ vs. Steatosis, $\mathrm{P}^{2}=$ Steatosis $/ \mathrm{HCV}$ vs. HCV

NKT and CD8 + T cells and the severity of

Steatosis: Patients with hepatic steatosis (groups 1 and 3) were classified based on the severity of steatosis into mild $(n=28)$, and moderate/severe $(n=72)$. No association was found between the frequency of NKT cells and the severity of steatosis. Higher frequencies of both NKT $\left(\mathrm{CD}^{+}\right)$ $\left.\mathrm{CD} 56^{+} / \mathrm{CD}_{161^{+}}\right)$cells and $\mathrm{CD} 8+\mathrm{T}$ cells were significantly associated with increased severity of steatosis $(p=0.03$ and 0.04 respectively). We further analyzed the frequency of NKT cells and CD8+ T cells in relation to the severity of steatosis in HCV patients. A significant association between CD8+ T cells (but not with NKT cells) and the advanced stages of steatosis was found $(p=0.001)$ (Table 5).

The correlation between NKT cells and clinical and lab. Variables: NKT cells positively correlated with steatosis $(r=0.40, p=0.001)$ and $\mathrm{BMI}(r=0.24, p=0.03)$. While, no correlations were found between NKT cells frequency and age, hematological or liver biochemical parameters, lipid profile or HCV RNA.

\section{Discussion}

$\mathrm{HCV}$ infection is one of the most important and potentially reversible causes of NAFLD ${ }^{(6)}$. It is closely associated with lipid metabolism throughout its lifecycle ${ }^{(26)}$, which explains the high incidence of hepatic steatosis (>50\%) NAFLD and HCV-related liver disease are common in the general population, but their concurrence is 2 to 3 times higher than would be explainable by chance alone in patients with chronic hepatitis $C^{(27,28)}$. Both NKT cells and CD8 ${ }^{+} T$-cells are known to play an important role in obesity-related adipose tissue inflammation. The relation between NAFLD and NKT cells had been the focus of many researches however, despite extensive studies, the exact pathogenesis of NAFLD remains unknown. Murine models clearly support a pivotal role of NKT cells in the pathogenesis of NAFLD however, data on the role of NKT cells in human NAFLD is limited. The results of the previous studies that investigated the relation between NKT cells and NAFLD had shown contradictory results. Due to the discrepancies in the results of NKT involvement in NAFLD patients, it is not known whether the concomitant $\mathrm{HCV}$ infection would exacerbate or correct the changes of NKT cells frequencies in those patients. The aim of this study was to assess the possible changes in the expression of peripheral blood NKT cells in patients with steatosis with concomitant HCV infection. Moreover, to assess whether these changes are related to the severity of hepatic steatosis. Our study showed an increase in the frequency of peripheral NKT cells of the phenotype 
$\left(C_{3}+/ C D_{56+/ C D 161+)}\right.$ among patients with either steatosis or concomitant HCV/steatosis compared to normal controls (7.1 \pm 4.5 and $8.8 \pm 5.8$ vs. $4.2 \pm 1.6, p<0.0001$ each). However, no difference in NKT frequency between HCV patients and control group was noted $(p=0.72)$. These data are in accordance with the findings observed by Adler and co-workers ${ }^{(29)}$ who noted that NKT cells increased significantly in both liver and blood of patients with NAFLD. Moreover, Tajiri et al. ${ }^{(11)}$ and Syn et al. ${ }^{(16)}$ had demonstrated a significant increase in the intrahepatic NKT cells in patients with NAFLD compared to healthy controls. A recent study reported the presence of an immunological signature of NASH that includes hepatic infiltrating NKT and $\mathrm{CD}^{+}$T-cells and concluded that depletion of these cells resulted in reduced NASH progression and presents novel therapeutic strategy for the treatment of $\mathrm{NASH}^{(24)}$. In contrast, other studies reported a depletion in the peripheral blood NKT cells in patients with clinically diagnosed NALFD ${ }^{(14,30,31)}$. Whereas Kremer et al (15) found that NKT cells depletion was associated with severe stages of steatosis. Moreover, animal experiments have suggested a link between NKT cell deficiency and NAFLD based on the reduction in hepatic NKT cells in leptin-deficient mice ${ }^{(32)}$. Additionally, adoptive transfer of NKT cells(33) or oral administration of liver-extracted proteins ${ }^{(34)}$ improved steatosis in leptin-deficient mice. These improvements were associated with an increase in the frequency of hepatic NKT cells.

Table 4: NKT cells in relation to severity of hepatic steatosis

\begin{tabular}{|l|c|c|c|}
\hline Type of cells (\%) & $\begin{array}{c}\text { Mild steatosis } \\
(\mathrm{n}=28)\end{array}$ & $\begin{array}{c}\text { moderate/severe steato- } \\
\text { sis } \\
(\mathrm{n}=72)\end{array}$ & $\mathrm{P}$ \\
\hline Lymphocytes (Total) & $42.4 \pm 9.1$ & $35.4 \pm 7.8$ & 0.6 \\
\hline $\mathrm{CD}^{+}$ & $61.6 \pm 7.3$ & $55.1 \pm 10.2$ & 0.4 \\
\hline $\mathrm{CD}^{+} / \mathrm{CD}^{+}$ & $38.4 \pm 7.1$ & $44 \pm 7.6$ & $\mathbf{0 . 0 4}$ \\
\hline $\mathrm{CD}^{+} / \mathrm{CD} 56^{+}$ & $22.5 \pm 18.3$ & $19.9 \pm 14.9$ & 0.6 \\
\hline $\mathrm{CD}^{+} / \mathrm{CD} 56^{+} / \mathrm{CD}_{161}{ }^{+}$ & $9.4 \pm 6.3$ & $12.1 \pm 5.2$ & $\mathbf{0 . 0 3}$ \\
\hline
\end{tabular}

Table 5: NKT cells and severity of steatosis in patients with concomitant steatosis and HCV

\begin{tabular}{|c|c|c|c|}
\hline \multirow[b]{2}{*}{ Type of cells (\%) } & \multicolumn{2}{|c|}{ HCV patients $(n=50)$} & \multirow[b]{2}{*}{$p$} \\
\hline & $\begin{array}{l}\text { mild steatosis } \\
\qquad(\mathrm{n}=28)\end{array}$ & $\begin{array}{l}\text { moderate/severe } \\
\text { steatosis }(n=22)\end{array}$ & \\
\hline Lymphocytes (Total) & $42.4 \pm 9.1$ & $40.4 \pm 8.8$ & 0.43 \\
\hline $\mathrm{CD}^{+}$ & $61.6 \pm 7.3$ & $65.1 \pm 12$ & 0.20 \\
\hline $\mathrm{CD}^{+} / \mathrm{CD}^{+}$ & $38.4 \pm 7.1$ & $46 \pm 8.7$ & 0.001 \\
\hline $\mathrm{CD}_{3}{ }^{+} / \mathrm{CD}_{5} 6^{+}$ & $22.5 \pm 18.3$ & $18.9 \pm 15.9$ & 0.47 \\
\hline $\mathrm{CD}_{3}{ }^{+} / \mathrm{CD}_{5} 6^{+} / \mathrm{CD}_{161^{+}}$ & $9.4 \pm 6.3$ & $8.03 \pm 5.3$ & 0.40 \\
\hline
\end{tabular}

Patients with chronic HCV infections, reported remarkably low numbers of intrahepatic $C_{3}+C_{5} 6+$ NKT-like cells, which may be related to their increased susceptibility for hepatocellular carcinoma ${ }^{(35)}$. The human classical NKT cells were detected in the livers of HCV-infected persons; however, their frequencies were decreased compared with healthy persons. A similar situation has been described in other infections (i.e. HIV-infection) ${ }^{(36,37)}$. NKT cells depletion in HIV-infected patients may be due 
to direct infection of these cells by the virus, however, in case of HCV infection, the decrease in the frequency of peripheral NKT cells was attributed to the down-regulation of $\mathrm{T}$ cell receptors, apoptosis of the cells and/or migration into peripheral organs( ${ }^{(30)}$. The controversies related to NKT studies could be, in part, related to the methodology used to evaluate peripheral NKT cells. For example, aGalCer/CD1d tetramers and $V_{\alpha 24 / V \beta 11}$ double-staining are two standard methods for NKT cell identification while, the use of Va24 staining alone may overestimate the numbers of Va24 and V $\beta 11$ double positive NKT cells ${ }^{(38)}$.

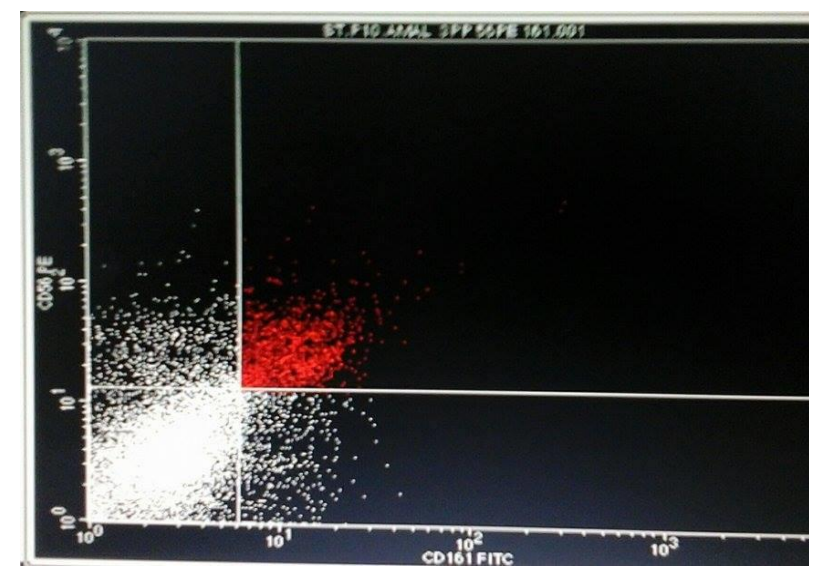

Figure 1a: Flowcytometry of NKT cells $\left(\mathrm{CD}_{5} 6^{+} / \mathrm{CD} 161^{+}\right)$in a patient with concomitant HCV and steatosis (8.7\%).

In addition, human liver sections from patients with NASH showed increased $C D 8^{+} T$ cells ${ }^{(24)}$. Our study supports the absence of a role of $\mathrm{HCV}$ infection in the increased frequency of NKT or CD8 ${ }^{+} \mathrm{T}$ cells in hepatic steatosis and suggests that the observed increase in both cell types is related to the steatosis condition itself with no added effect of the concomitant HCV infection in those patients. Since no significant difference was noted in the percentages of NKT or $\mathrm{CD}^{+} \mathrm{T}$ cells in patients with concomitant HCV and steatosis when compared to those with steatosis alone. On the other hand, NKT cells were significantly higher in
As regards $C D 8+T$ cells, a significant increase was noted in the three patients' groups compared to control. Similarly, an early study had reported a decreased CD4+ cells and a corresponding increase in CD8+ $\mathrm{T}$ cells in chronic hepatitis $\mathrm{C}$ model(39). CD8 ${ }^{+} T$ and NKT cells play an important role in obesity-related adipose tissue inflammation. A recent study had assessed the role of NKT cells and CD8 ${ }^{+}$-cells on the development of NASH. The study used CD1d-deficient and $C D 8^{+} T$-cell-depleted mice that were subjected to high-fat high-carbohydrate (HFHC) diet for 16 weeks, after which the tested mice showed increased NKT-cell and $C D 8^{+} T$-cell infiltration in the liver.

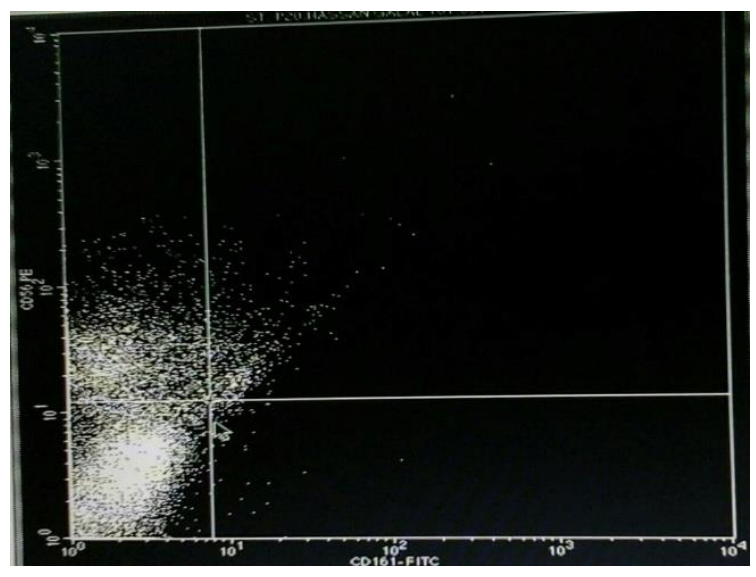

Figure 1b: Flowcytometry of NKT cells (CD $\left.56^{+} / \mathrm{CD} 161^{+}\right)$ in a patient with $\mathrm{HCV}$ alone (3.2\%).

patients with steatosis/HCV compared to those with HCV alone. Percentages of NKT and $C D^{+} T$ cells were significantly higher in moderate/severe steatosis compared to mild form in all steatosis patients. Accordingly, a recent study has supported the association between increased NKT and CD8+Tcells and the severity of NAFLD experimentally. In this study, mice were fed high Fat and carbohydrate diet to induce progressive NASH, the livers of these mice showed increased NKT cells and CD8 ${ }^{+} \mathrm{T}$-cell infiltration, while NKT-cell deficient and $\mathrm{CD} 8^{+} \mathrm{T}$-cell-depleted mice were protected against the progression of the advance 
form of NAFLD (i.e. NASH) ${ }^{(24)}$. Nevertheless, an earlier study by Adler et al,(29) demonstrated that NAFLD patients with moderate or severe steatosis had a higher percentage of both intrahepatic and peripheral NKT cells than did patients with mild steatosis or those without steatosis which supports the role of NKT cells in NAFLD. In steatosis/HCV group, we found comparable NKT frequencies between mild and moderate/severe steatosis. These results further support that the changes in the expression of NKT cells is related to the state of steatosis itself and not to the concomitant $\mathrm{HCV}$ infection. Unlikely, $\mathrm{CD} 8^{+} \mathrm{T}$ cells were higher in advanced stages of steatosis of steatosis. In our study, NKT cells positively correlated with hepatic steatosis and BMI. Accordingly, an earlier study by $\mathrm{Xu}$ and colleagues ${ }^{(14)}$ reported a correlation between the frequency of NKT cells and liver disease in patients who had a metabolic predisposition to NAFLD despite the lower frequency of peripheral NKT cells in those patients. Unlike our findings, they reported a negative correlation between NKT and BMI and concluded that the decreased frequency of peripheral NKT cells was a risk factor for NAFLD.

\section{Study limitations}

Since most of HCV cases are associated with steatotic changes in their course of the disease, it was not easy to obtain a larger number of HCV patients without steatosis and to have them matched for age and gender with the other study groups. Also, liver biopsies were not available for all the study population as it was not convenient to get liver tissue from healthy control due to ethical reasons.

\section{Conclusion}

Our results conclude that NKT and $C D 8^{+} T$ cells are significantly elevated in patients with hepatic steatosis irrespective to the presence or absence of concomitant HCV infection. In other words, the changes in NKT expression in hepatic steatosis is not augmented by the presence of concomitant HCV infection.

\section{Conflicts of interest: None}

\section{References}

1. McCullough AJ. Pathophysiology of non-alcoholic steatohepatitis. J Clin Gastroenterol. 2006; 40(1):17-29.

2. Schreuder TC1, Verwer BJ, van Nieuwkerk CM, Mulder CJ. Nonalcoholic fatty liver disease: an overview of current insights in pathogenesis, diagnosis and treatment. World J Gastroenterol. 2008;14(16):2474-86.

3. Blomme B, Francque $S$, Trépo $E$, et al. $\mathrm{N}$-glycan Based biomarker distinguishing non-alcoholic steatohepatitis from steatosis independently of fibrosis. Liver Dis. 2011; 74(3):389-94.

4. Vere CC, Neagoe D, Streba CT, et al. Steatosis and serum lipid patterns in patients with chronic viral hepatitis: differences related to viral etiology. Rom J Morphol Embryol. 2010; 51 (3):509-14.

5. Liakina $V$, Speiciené D, Irnius A, Semuchiniené T, Valantinas J. Association of the prevalence and grade of steatosis in patients with chronic hepatitis $C$ with the host and viral factors, Acta Gastroenterol Belg. 2007; 70(3):260-6.

6. Lonardo A, Adinolfi LE, Loria P, Carulli $N$, Ruggiero G, Day CP. Steatosis and hepatitis $C$ virus: mechanisms and significance for hepatic and extrahepatic disease. Gastroenterology, 2004; 126(2):586-97.

7. Adinolfi LE, Gambardella M, Andreana A, Tripodi MF, Utili R, Ruggiero G. Steatosis accelerates the progression of liver damage of chronic hepatitis C patients and correlates with specific $\mathrm{HCV}$ genotype and visceral obesity. Hepatology, 2001; 33(6):1358-64.

8. Ohata K, Hamasaki K, Toriyama K, et al. Hepatic steatosis is a risk factor for 
hepatocellular carcinoma in patients with chronic hepatitis $C$ virus infection. Cancer. 2003; 97(12):3036-43.

9. Wu D, Xing GW, Poles MA, Horowitz A, Kinjo $Y$, Sullivan B. Bacterial glycolipids and analogs as antigens for CD1d-restricted NKT cells. Proc Natl Acad Sci USA. 2005; 102(5):1351-6.

10. Berzofsky JA, Terabe M. NKT cells in tumor immunity: opposing subsets define a new immunoregulatory axis. J Immunol. 2008; 180(6):3627-35.

11. Tajiri K, Shimizu Y, Tsuneyama K, Sugiyama T. Role of liver-infiltrating $\mathrm{CD}_{3}+\mathrm{CD}_{56} 6$ natural killer T cells in the pathogenesis of nonalcoholic fatty liver disease. Eur J Gastroenterol. Hepatol. 2009; 21(6):673-80.

12. Godfrey DI, Hammond KJ, Poulton LD, Smyth MJ, Baxter AG. NKT cells: facts, functions and fallacies. Immunol Today. 2000; 21(11):573-83.

13. Li Z, Lin H, Yang S, Diehl AM. Murine leptin deficiency alters Kupffer cell production of cytokines that regulate the innate immune system. Gastroenterology. 2002; 123(4):1304-10.

14. Xu CF, Yu CH, Li YM, Xu L, Du J, Shen Z. Association of the frequency of peripheral natural killer T cells with nonalcoholic fatty liver disease. World $\mathrm{J}$ Gastroentrol. 2007; 13(33): 4504-8.

15. Kremer M, Thomas E, Milton RJ, et al. Kupffer cell and interleukin-12- dependent loss of natural Killer T cells in hepatosteatosis. Hepatology, 2010; 51(1):130-41.

16. Syn WK, Oo YH, Pereira TA, et al. Accumulation of natural killer $\mathrm{T}$ cells in progressive nonalcoholic fatty liver disease. Hepatology, 2010; 51(6):19982007.

17. Shiratori Y, Kawase T, Komatsu Y, et al. Endotoxin induced cellular communication in the liver: murine models for clarification of the role of LPS responsive macrophages in the pathogenesis of liver diseases. J Gastroenterol Hepatol. 1995; 10(1):97-100.
18. Liu C, Zhu H, Tu Z, Xu YL, Nelson DR. CD8+ T-cell interaction with HCV replicon cells: evidence for both cytokineand cell-mediated antiviral activity. Hepatology. 2003; 37:1335-1342.

19. Cox AL, Mosbruger T, Lauer GM, Pardoll D, Thomas DL, Ray SC. Comprehensive analyses of CD8+ $T$ cell responses during longitudinal study of acute human hepatitis C. Hepatology. 2005; 42:104-112.

20. Urbani S, Amadei B, Fisicaro P, et al. Outcome of acute hepatitis $C$ is related to virus-specific $\mathrm{CD} 4$ function and maturation of antiviral memory CD8 responses. Hepatology. 2006; 44:126139.

21. Kaplan DE, Sugimoto K, Newton $K$, et al. Discordant role of $\mathrm{CD}_{4} \mathrm{~T}$-cell response relative to neutralizing antibody and CD8 T-cell responses in acute hepatitis C. Gastroenterology. 2007; 132:654-666.

22. Gruener NH, Lechner F, Jung MC, et al. Sustained dysfunction of antiviral CD8+ T lymphocytes after infection with hepatitis C virus. J Virol. 2001; 75:5550-5558.

23. Wedemeyer $\mathrm{H}$, He XS, Nascimbeni $M$, et al. Impaired effector function of hepatitis C virus-specific CD8+ T cells in chronic hepatitis $\mathrm{C}$ virus infection. $\mathrm{J} \mathrm{Im}$ munol. 2002; 169:3447-3458.

24. Bhattacharjee J, Kumar JM, Arindkar S, et al. Role of immunodeficient animal models in the development of fructose induced NAFLD. J Nutr Biochem 2014;25: 219-226.

25. Brunt EM, Janney CG, Di Bisceglie AM, Neuschwander- Tetri BA, Bacon BR. Nonalcoholic steatohepatitis: a proposal for grading and staging the histological lesions. Am J Gastroenterol. 1999; 94(9): 2467-74.

26. Patel J, Goyal S, Cafazzo JA, Liu JS, Shen TC. Hepatitis $C$ and hepatic steatosis. QJM, 2010; 103 (5): 293-303.

27. Ramalho F. Hepatitis $C$ virus infection and liver steatosis. Antiviral Res. 2003; 6o(2):125-7. 
28. Hwang SJ, Luo JC, Chu CW, Lai CR, Lu $\mathrm{CL}$, Tsay SH. Hepatic steatosis in chronic hepatitis C virus infection: prevalence and clinical correlation. J Gastroenterol Hepatol. 2001; 16(2):190-5.

29. Adler M, Taylor S, Okebugwu K, et al. Intrahepatic natural killer $t$ cell populations are increased in human hepatic steatosis. World J Gastroenterol. 2011; 17(13):1725-31.

30. Lucas M, Gadola S, Meier U, et al. Frequency and phenotype of circulating Valpha24/Vbeta11 double-positive natural killer T cells during hepatitis $C$ virus infection. J Virol. 2003; 77(3): 2251-7.

31. Godfrey DI and Kronenberg M. Going both ways: immune regulation via CD1d-dependent NKT cells. J Clinic. Invest. 2004; 114(10):1379-88.

32. Guebre-Xabier $M$, Yang $S$, Lin $H Z$, Schwenk R, Krzych U, Diehl AM. Altered hepatic lymphocyte subpopulations in obesity-related murine fatty livers: potential mechanism for sensitization to liver damage. Hepatology. 2000; 31(3):633-40.

33. Elinav E, Pappo O, Sklair-Levy M, et al. Adoptive transfer of regulatory NKT lymphocytes ameliorates non-alcoholic steatohepatitis and glucose intolerance in ob/ob mice and is associated with intrahepatic CD8 trapping. J Pathol. 2006a; 209: 121-8.
34. Elinav E, Pappo O, Sklair-Levy M, et al. Amelioration of non-alcoholic steatohepatitis and glucose intolerance in ob/ob mice by oral immune regulation towards liver-extracted proteins is associated with elevated intrahepatic NKT lymphocytes and serum IL-10 levels. J Pathol. 2006b; 208: 74-81.

35. Kawarabayashi N, Seki S, Hatsuse K, et al. Decrease of $\mathrm{CD} 56^{+} \mathrm{T}$ cells and natural killer cells in cirrhotic livers with hepatitis C may be involved in their susceptibility to hepatocellular carcinoma. Hepatology. 2000;32(5):962-969.

36. van der Vliet HJ, von Blomberg BM, Hazenberg MD, et al. Selective decrease in circulating $\mathrm{V}$ a $24 a \mathrm{~V}$ a 11a NKT cells during HIV type 1 infection. J. Immunol. 2002; 168, 1490-5.

37. Motsinger A, Haas DW, Stanic AK, Van Kaer L, Joyce S, Unutmaz D. CD1d-restricted human natural killer T cells are highly susceptible to human immunodeficiency virus 1 infection. J. Exp. Med. 2002; 195, 869-79.

38. Metelitsa LS. Flow cytometry for natural killer T cells: multiparameter methods for multifunctional cells. Clin Immunol. 2004; 110: 267-76.

39. Panasiuk A, Prokopowicz D, Zak J, Wysocka J. Peripheral blood T, B, and NK cells in relation to histological hepatitis activity and fibrosis stage in chronic hepatitis C. Hepato-gastroenterology. 2003;50(49):178-182. 